Original Research Report

\title{
Obstetrical Factors in Postpartum Depression: A Correlational Study at General Hospitals of Banjarmasin
}

\author{
Winda Ayu Fazraningtyas ${ }^{1}$, Anggrita Sari ${ }^{2}$, Dini Rahmayani ${ }^{1}$ \\ ${ }^{1}$ Maternity Nursing Department, Nursing Program, Faculty of Health, Sari Mulia \\ University. Banjarmasin, Indonesia. \\ ${ }^{2}$ Midwifery Department, Midwifery Program, Faculty of Health, Sari Mulia \\ University. Banjarmasin, Indonesia.
}

Article History
Received:
27.02 .2020
Revised:
29.02 .2020
Accepted:
03.03 .2020
*Corresponding Author:
Winda Ayu Fazraningtyas
Email:
windaayu@unism.ac.id

This is an open access article, licensed under: $\mathrm{CC}-\mathrm{BY}-\mathrm{SA}$
Abstract: Problematic health areas such as maternal and child health is one of the target areas to be addressed so that by 2030 , reduction of maternal mortality by less than 70 per 100,000 live births will be attained. Mental illness that happens in postpartum women is significantly associated with morbidity and disability. There are about $10 \%$ of pregnant women and $13 \%$ of mothers who experience mental disorder, especially depression worldwide. This study aimed to determine and analyze the obstetrical factors associated with postpartum depression. This study used quantitative design with descriptive survey method. A total of 88 participants were included coming from the two General Hospital in Banjarmasin, South Kalimantan, Indonesia. EPDS, BDI-II, and PPDRF checklist were used. It was found out that there is no significant association between the level of depression and desire to be pregnant, complication in pregnancy, and history of abortion. However, there is a significant relationship between participants' level of depression and their experience of menstrual problems. There are 15 or $17 \%$ mothers who suffered severe postpartum depression in both hospitals. This needs to be a concern for health workers because postpartum depression mothers could have a poor relationship with children, difficulty meeting their daily needs, caring for children, or even developing into postpartum psychosis.

Keywords: Complication in Pregnancy, Menstrual Problem, Obstetrical Factors, Postpartum Depression. 
Winda Ayu Fazraningtyas, Anggrita Sari, Dini Rahmayani.

Obstetrical Factors in Postpartum Depression: A Correlational Study at General Hospitals of Banjarmasin.

International Journal of Clinical Inventions and Medical Sciences, vol. 2, no. 1, pp. 8-14, March 2020. DOI: 10.36079/lamintang.ijcims-0201.74

\section{Introduction}

In the Year 2015, the United Nations set the Sustainable Development Goals (SGDs). SGD's main goal is to end poverty, protect the planet, and ensure prosperity for all. There are 17 long-term goals formulated to achieve these 3 main goals. One of the goals to be achieved within the scope of health is stated in the 13th SGD, which is good health and well-being [1]. Maternity deaths are particularly high because postpartum women belong to the vulnerable group, who are expected to experience physiologic changes experienced during postpartum, both physically and psychologically [2] [3].

Psychological changes during the postpartum period bring changes in certain attitudes and feelings of postpartum women and require adaptation [4]. Moreover, during pregnancy, body changes experienced by a postpartum woman also affects her psychological condition. Depression, occurring in mothers, can appear in the postnatal or postpartum period. Postpartum depression is like a thief which takes away the happiness and compassion that a mother feels and is given to a newborn [5]. Additionally, mothers with postpartum depression feel difficulty to conduct and complete daily activities [6].

According to $\mathrm{CDC}$ [7], about 1 in 9 women experience postpartum depression. According to a study by [8] the prevalence of postpartum depression and anxiety in women from Asian countries were higher compared to Western countries. Meanwhile, in Indonesia, the incidence of depression is not known exactly, either for pregnant women or after childbirth. However, according to a study conducted by [9] in the City of Denpasar, it revealed that as much as $20.5 \%$ experienced postpartum depression.

According to Humayun et. al. [10], mental health is important to note but often a neglected component of reproductive health. Hence, the study on postpartum depression conducted in Indonesia is still limited, especially in Banjarmasin. Several studies conducted in Indonesia only focused on socio-demographic factors. Therefore, a study on postpartum depression is considered. Thus, this study aimed to determine and analyze the obstetrical factors associated with postpartum depression.

\section{Literature Review}

Postpartum depression is a depression syndrome that is not a symptom of psychosis that occurs in the mother after childbirth and can be prevented and cured although is often unrecognized and undertreated [11] [12] [13]. Postpartum depression is characterized by changing mood, nervousness, irritability, depression, fear, and obsession phenomenon [4] [14] [15]. Furthermore, postpartum depression is much influenced by the state of the mother in the second and third trimester. These symptoms can appear 2 or 3 days after delivery and usually disappear within 1 or 2 weeks. In addition, symptoms can develop from pregnancy but persist until after delivery [12].

The postpartum depression condition happens when it is triggered by feeling tired accompanied with irritability [13] [16]. This takes place among new mothers because they face many life changes and adjustments such as new patterns, household tasks and routine. Postpartum stress has consistently been linked to the mood and well-being of mothers [14].

Causes of postpartum depression are unknown [4] [11] [12] [17] [18] [19] [20]. According to NIMH [15], postpartum depression is not caused by a single cause, but rather a combination of physical and emotional factors. In addition, depression during pregnancy is the same mood disorder that occurs in depression in general people where, in the event of depression, there will be chemical changes in the brain [21]. However, hormonal role is the most contributing factor to the cause of postpartum depression [4] [22] [23].

Hormonal changes in women during the reproductive cycle, such as menstruation, pregnancy, and menopause cause women to become more sensitive [11]. This is due to a decrease of estrogen (estradiol) and progesterone drastically [4] [11] [22] [24]. Progesterone increases up to 20 times higher during pregnancy and keeps increasing until the end of the pregnancy period while the estradiol levels increase is around 200-300 times in about 20 weeks gestation and remains high for the remainder of the pregnancy [24]. Both hormones are down drastically during the expulsion of the placenta [4] [24].

The study by Schiller [23], revealed that the pathophysiology of postpartum depression associated with the hormone withdrawal hypothesis and estradiol affects women with postpartum depression negatively. Besides, corticosterone, Corticotropic Releasing Hormone (CRH), and oxytocin are also changing [24]. 
Winda Ayu Fazraningtyas, Anggrita Sari, Dini Rahmayani.

Obstetrical Factors in Postpartum Depression: A Correlational Study at General Hospitals of Banjarmasin.

International Journal of Clinical Inventions and Medical Sciences, vol. 2, no. 1, pp. 8-14, March 2020. DOI: 10.36079/lamintang.ijcims-0201.74

The signs and symptoms of postpartum depression are overwhelming sadness which can happen to both new mothers and fathers [4]. Both women and men are very effective in their treatment of infant's health, insecurity, psychosomatic symptoms, restlessness, and either depressive or extreme mood fluctuations [4] [6]. Additionally, symptoms that occur also include changes in sleep patterns, eating, and activity [11]. A narrative review suggested that women with postpartum depression can have comorbid symptoms such as panic attacks, obsessions, compulsions, or psychotic features [25].

\section{Methods}

This study used quantitative design using descriptive survey methods. A 100 participants were screened using Edinburg Postnatal Depression Scale (EPDS), Beck Depression Inventory (BDI)-II instruments, and Postpartum Depression Risk Factors (PPDRF) checklist. Nonetheless, 12 participants were excluded because participants did not match the criteria set by the researcher.

This research began by screening postpartum women who were admitted in the hospital then the researcher conveyed the purpose of the research and explained the contents of the questionnaires. The researcher also emphasized that the data and the responses of the participants will be kept confidential and will not be leaked to other parties. The participants were asked to fill out the informative consent sheet and questionnaires provided. The researcher assessed the scores obtained by the participants and analyzed the obstetrical factors.

Descriptive statistic was used to describe the participants' characteristics that include frequencies and percentages. Participants' characteristics include desire to be pregnant, complication in pregnancy, history of abortion, and menstrual problem. Data analysis used in this study was chisquare test where this analysis was used to know the relationship of level of depression and the risk factors of postpartum depression. The significance level $(\alpha)$ that was used in this study was 0.05 .

\section{Result and Discussion}

\subsection{Obstetrical Characteristics}

Table 1 shows the frequency and percentage of the participants' profile when grouped according to obstetrical characteristics. Obstetrical characteristics that assess in this research are desire to be pregnant, complication in pregnancy, history of abortion, and menstrual problem. In terms of desire for pregnancy, majority of the participants have planned pregnancies while $13.6 \%$ of them have unplanned pregnancies. A planned pregnancy meant that parents have a clear plan for pregnancy and parenting. Pregnancy needs to be well planned so that later, they could bear a healthy child. Meanwhile, unplanned pregnancy means a pregnancy that occurs without careful planning of the parents. An unplanned pregnancy can be an unwanted pregnancy when there is strong resistance from the parents [26].

Table 1. Frequency and Percentage Distribution of the Participants' Profile When Grouped According To Obstetrical Characteristics

\begin{tabular}{lccc}
\hline Obstetrical Characteristics & Specific Variables & Frequency & Percentage \\
\hline Desire to be Pregnant & Unplanned & 12 & 13.60 \\
& Planned & 76 & 86.40 \\
Complication in Pregnancy & & 76 & 86.40 \\
& No & 12 & 13.60 \\
\multirow{3}{*}{ History of Abortion } & Yes & 80 & 90.90 \\
& & 8 & 9.10 \\
Menstrual Problem & No & & \\
& Yes & 83 & 94.30 \\
& & 5 & 5.70 \\
\hline
\end{tabular}

Majority of the participants in this study did not experience complications during pregnancy while $13.6 \%$ of them experienced complications during pregnancy. Some of the complications during 
pregnancy that occurred in participants in this study were hypertension, pre-eclampsia, gestational diabetes, and others. If women had experience of complication in pregnancy, they tended to have developed complications in future pregnancies [27].

As regards abortion cases, about $90.9 \%$ of the participants had no history of abortion while $9.1 \%$ of them had history of abortion. Abortion can emotionally affect each woman differently. Some women reported a sense of relief after having an abortion. One important factor related to the vulnerability of negative emotional or psychological effects has to do with the belief about the inside of one's person. Those who believe it is not a baby until it is born have less a chance of experiencing negative emotional consequences. However, those who believe it is a baby are more likely to experience negative emotional side effect [6].

In terms of menstrual problems, only 5 of the participants experienced menstrual problems while majority did not experience such. Usual menstrual problems experienced by the mothers are dysmenorrheal and irregular menstruation among others.

\subsection{Level of Depression}

Table 2 described the frequency distribution and percentage of participants' level of depression. This study used two instruments in assessing levels of depression namely Edinburg Postnatal Depression Scale (EPPDS) and Beck Depression Inventory-II (BDI-II). Based on the result, it can be noted that a little more than half of the participants have mild levels of depression while the others had either moderate or severe levels. Moderate postpartum mothers show symptoms of disorders that may cause anxiety while postpartum mothers with severe levels require proper handling and are referred to a psychiatrist [28].

Table 2. Frequency and Percentage Distribution of the Participants' Level of Depression

\begin{tabular}{lcc}
\hline Level of Depression & Frequency & Percentage \\
\hline Mild & 50 & 56.80 \\
Moderate & 23 & 26.10 \\
Severe & 15 & 17.00 \\
\hline
\end{tabular}

The study by Dira and Wahyuni [9] in Denpasar, Bali showed that there is a prevalence of 20.5\% postpartum depression cases based on EPDS score of about 9 participants out of a total of 44 participants with severe depression. Meanwhile, the study of [29] in a tertiary hospital in Dasmarinas, Cavite, Philippines revealed that the prevalence of postpartum depression was $22.61 \%$. Moreover, the cross-sectional study conducted among Canadian Women found out that the prevalence rates of postpartum depression ranged from $8.46 \%$ to $8.69 \%$ [30].

Depression affects about 121 million people worldwide. At its most, severe depression can lead to suicide and is responsible for 850,000 deaths every year and, by 2020, it is expected to be the largest contributor to disease burden [31]. Depression is particularly common among women. Although depression is the leading cause for both males and females, the burden of depression is $50 \%$ higher for females than males [32].

\subsection{Level of Depression and Obstetrical Characteristics}

In terms of complications during pregnancy, Table 3 reflects a probability value of 0.207 . This indicates that there is no significant relationship between participants' level of depression and complications in pregnancy. According to a meta-analysis study, it is revealed that obstetric complications are weakly associated with postpartum depression [33]. Early handling and clarification from midwives and other health workers on complications experienced by participants cause participants not to worry about the complications that they experienced; also, the nurses, midwives and doctors can give the right treatment.

In addition, complications in pregnancy also do not affect the condition of the mother during the puerperium especially if a mother has a healthy child and the delivery process went well. However, if it turns out that the child's condition is not normal and the delivery process does not run well, it will affect the condition of the mother [34]. 
Winda Ayu Fazraningtyas, Anggrita Sari, Dini Rahmayani.

Obstetrical Factors in Postpartum Depression: A Correlational Study at General Hospitals of Banjarmasin.

International Journal of Clinical Inventions and Medical Sciences, vol. 2, no. 1, pp. 8-14, March 2020. DOI: 10.36079/lamintang.ijcims-0201.74

Table 3. Chi-Square Test on the Significant Relationship between Levels of Depression and Psychological Characteristics

\begin{tabular}{lrr}
\hline \multicolumn{1}{c}{ Obstetrical Characteristics } & $\chi^{2}$ value $\mathrm{df}=10$ & P-value \\
\hline Desire to be Pregnant & $5.921^{\mathrm{a}}$ & 0.052 \\
Complication in Pregnancy & $3.147^{\mathrm{a}}$ & 0.207 \\
History of Abortion & $0.161^{\mathrm{a}}$ & 0.923 \\
Menstrual Problem & $14.976^{\mathrm{a}}$ & 0.001 \\
\hline
\end{tabular}

In terms of desire to be pregnant, based on the probability value of 0.052 which is greater than the significant level (0.05), the null hypothesis is accepted. This means that there is no significant relationship between participants' level of depression and their desire to be pregnant. Pregnancy is planned to make the parents ready with all the consequences that occur during pregnancy. Moreover, the planned pregnancy is also to get more social support especially from husband and family members. Conversely, mothers tend to be less prepared with all the consequences during pregnancy [35].

In terms of history of abortion, it can be deduced that there is no significant relationship between participants' level of depression and history of abortion which is supported by the probability value of 0.923. A study by [36] argued that most adult women who terminate the pregnancy tend to have mental health problems. However, women's psychological experience of abortion is not the same. It varies as a function of their personal characteristics, events that leads up to the pregnancy, the circumstances of their lives and relationships at the time that a decision to terminate the pregnancy is made, the reasons for, type, and timing of the abortion, events and conditions that occur in their lives during and subsequent to an abortion, and, the larger social-political context in which abortion takes place.

On the contrary, a study conducted in Malaysia showed that there is a significant relationship between the level of depression and history of abortion. A mother with a history of abortion may inevitably suffer a process of grief and mourning which may last for a longer period. Women may need a longer period to recover, at least partially, from the long-term effects of abortion on their physical and mental well-being [37].

In terms of menstrual problems, the obtained probability value of 0.001 is smaller than the significant level (0.05) which leads to the rejection of the null hypothesis. This indicates that there is a significant relationship between the level of depression and menstrual problems. It can be seen further in the table that most of those who experienced menstrual problems have a level of depression which is categorized as "severe" level. This result is in line with the study of [38] which proposed that there is a significant relationship between the level of depression and premenstrual syndrome or premenstrual dysphoric women who are vulnerable to depression around the time of the heightened sensitivity to the accompanying hormone fluctuations. Those hormonal fluctuations could influence neurochemical pathways linked with depression. Furthermore, women with premenstrual syndrome have demonstrated symptoms as abnormal response to normal hormonal fluctuations [39].

\section{Summary and Conclusion}

This study aimed to determine and analyze the obstetrical factors associated with postpartum depression. This study was conducted in two hospitals of Banjarmasin City namely Ulin General Hospital and Dr. H. M. Ansari Saleh General Hospital of Banjarmasin. Participants in this study were postpartum women who did not experience comorbidities and had the same result assessment for both instruments; i.e., EPDS and BDI-II. There are 15 or $17 \%$ mothers who suffered severe postpartum depression in both hospitals. Furthermore, the menstrual problems are associated with hormonal changes experienced by postpartum mothers. This also happens because of hormonal changes during reproductive cycle, i.e., menstruation, pregnancy, and menopause. The cycle makes a woman more sensitive.

This research can be used as a basis for further research. Qualitative research is suggested to gain valuable insights of postpartum mothers with a depressive condition and also the coping mechanism that the mothers use. 
Winda Ayu Fazraningtyas, Anggrita Sari, Dini Rahmayani.

Obstetrical Factors in Postpartum Depression: A Correlational Study at General Hospitals of Banjarmasin.

International Journal of Clinical Inventions and Medical Sciences, vol. 2, no. 1, pp. 8-14, March 2020. DOI: 10.36079/lamintang.ijcims-0201.74

\section{References}

[1] United Nations (UN), Sustainable Development Goals: 17 goals to transform our world. (n.d). [Online]. Available: www.un.org/sustainabledevelopment/health/. [Accessed: October 2019].

[2] J. H. Park, W. Karmaus, and H. Zhang, "Prevalence of and risk factors for depressive symptoms in Korean women throughout pregnancy and in postpartum depression," Asian Nursing Research, vol. 9, pp. 219-225, 2015. doi: 10.1016/j.anr.2015.03.004. [Accessed: October 2019].

[3] A. Josefsson, C. Larsson, G. Sydsjo, and P. O. Nylander, "Temperament and character in women with postpartum depression," Arch Womens Ment Health, vol. 10, pp. 3-7, 2007. doi: 10.1007/s00737-006-0159-3. [Accessed: October 2019].

[4] A. Pillitteri, Maternal \& child health nursing: Care of the childbearing \& childrearing family (7th Ed.). Philippines: Lippincott Williams \& Wilkins, 2014.

[5] C. T. Beck, Postpartum depression: A metasynthesis. Qual Health Res, vol. 12, no. 4, pp. 453472, 2002. doi: 10.1177/104973202129120016. [Accessed: October 2019].

[6] American Psychological Association (APA), What is postpartum depression \& anxiety, 2017. [Online]. Available: www.apa.org/pi/women/resources/reports/postpartum_depression.aspx. [Accessed: October 2019].

[7] Centers for Disease Control and Prevention (CDC), Postpartum depression, 2017. [Online]. Available: http://www.cdc.gov/reproductivehealth/depression/index.htm. [Accessed: October 2019].

[8] A. Haque, A. Namawar, and K. A. Breene, "Prevalence and risk factors of postpartum depression in Middle Eastern/Arab women," Journal of Muslim Mental Health, vol. 9, no. 1, pp. 65-84, 2015. doi: http://dx.doi.org/10.3998/jmmh.10381607.0009.104. [Accessed: October 2019].

[9] I. K. P. A. Dira and A. A. S. Wahyuni, "Prevalensi dan faktor risiko depresi postpartum di Kota Denpasar menggunakan Edinburg Postnatal Depression Scale," E-JURNAL MEDIKA, vol. 5, no. 7, pp. 1-5, 2016. [Online]. Available: http://ojs.unud.ac.id/index.php/eum. [Accessed: October 2019].

[10] A. Humayun, I. I. Haider, N. Imran, H. Iqbal, and N. Humayun, "Antenatal depression and its predictors in Lahore, Pakistan," East Mediterr Health J., vol. 19, no. 4, pp. 327-332, 2013 Antenatal_depression_and_its_predictors_in_Lahore_Pakistan. [Online]. Available: https:// www.researchgate.net/publication/249011231. [Accessed: October 2019].

[11] M. Patel, R. K. Bailey, S. Jabeen, S. Ali, N. C. Barker, and K. Osiezagha, "Postpartum depression: A review," J Health Care Poor Underserved, vol. 23, no. 2, pp. 534-542, 2012. doi: 10.1353/hpu.2012.0037. [Accessed: October 2019].

[12] N. J. Klossner and N. T. Hatfield, Introductory maternity \& pediatric nursing (2nded.). Philadelphia: Lippincott Williams \& Wilkins, 2010.

[13] I. M. Bobak and M. D. Jensen, Essential of maternity nursing. St. Louis, MO: Mosby, 1991.

[14] J. Norliza, S. A. S. Khuzaimah, A. S. Emad, and S. Norimah, "Depression and coping strategies used by postnatal mothers during the postpartum period," MJP, 2014. [Online]. Available: https://www.researchgate.net/publication/274569348_Depression_and_Coping_Strategies_Use d by_Postnatal_Mothers_During the Postpartum_Period. [Accessed: October 2019].

[15] National Institute of Mental Health (NIMH), Postpartum depression facts, (n.d). [Online]. Available: https://www.nimh.nih.gov/health/publications/postpartum-depression-facts/index. shtml. [Accessed: October 2019].

[16] E. J. Corwin, J. Brownstead, N. Barton, S. Heckard, and K. Morin, "The impact of fatigue on the development of postpartum depression," JOGNN, vol. 34, pp. 577-586, 2005. doi: 10.1177/0884217505279997. [Accessed: October 2019].

[17] J. Y. Ko, K. M. Rockhill, V. T. Tong, B. Morrow, and S. L. Farr, "Trends in postpartum depressive symptoms-27 states, 2004, 2008, and 2014," Centers for Disease Control: MMWR, vol. 66, no. 6, pp. 154-158, 2017.

[18] V. Sharma and P. Sharma, "Postpartum depression: Diagnostic and treatment issues," J Obstet Gynaecol Can, vol. 34, no. 5, pp. 436-442, 2012.

[19] C. B. Nemeroff, "Understanding the pathophysiology of postpartum depression: Implications for the development of novel treatments," Neuron, vol. 59, pp. 185-186, 2008. doi: 10.1016/j.neuron.2008.07.015. [Accessed: October 2019]. 
[20] L. H. Chaudron, "Postpartum depression: What pediatricians need to know," Pediatrics in review, vol. 24, no. 5, pp. 154-160, 2003.

[21] E. S. Kurniawan, N. Ratep, and W. Westa, Faktor penyebab depresi pada ibu hamil selama asuhan antenatal setiap trimester. (n.d) [Online]. Available: http://download.portalgaruda. org/article.php?article=14481\&val=970. [Accessed: October 2019].

[22] C. E. Schiller, S. Meltzer-Brody, and D. R. Rubinow, "The role of reproductive hormones in postpartum depression," CNS Spectr, vol. 20, no. 1, pp. 48-59, 2015. doi: 10.1017/S1092852914000480. [Accessed: October 2019].

[23] C. E. E. Schiller, The hormone withdrawal hypothesis of postpartum depression: a translational approach. Doctoral dissertation, University of Iowa, Iowa, 2011. [Online]. Available: http://ir.uiowa.edu/cgi/viewcontent.cgi?article=2645\&context=etd. [Accessed: October 2019].

[24] S. Brummelte and L. A. M. Galea, "Postpartum depression: Etiology, treatment and consequences for maternal care," Hormone and Behavior, vol. 77, pp. 153-166, 2016. doi: 10.1016/j.yhbeh.2015.08.008. [Accessed: October 2019].

[25] M. Ghaedrahmati, A. Kazemi, G. Kheirabadi, A. Ebrahimi, and M. Bahrami, "Postpartum depression risk factors: A narrative review," J Educ Health Promot, vol. 6, no. 60, pp. 4-20, 2017. doi: 10.4103/jhep.jhep_9_16. [Accessed: October 2019].

[26] detik Health, Kehamilan Tidak Direncanakan, Berkah atau Musibah?, 2013. [Online]. Available: https://health.detik.com/ulasan-khas/2162270/kehamilan-tidak-direncanakan-berkah -atau-musibah. [Accessed: October 2019].

[27] R. Neiger, "Long-term effect of pregnancy complications on maternal health: A review," J Clin Med, vol. 6, no. 8, pp. 1-12, 2017. doi: 10.3390/jcm6080076. [Accessed: October 2019].

[28] J. L. Cox, J. M. Holden, and R. Sagovsky, "Detection of postnatal depression: Development of the 10-item Edinburg Postnatal Depression Scale," British Journal of Psychiatry, vol. 150, pp. 782-786, 1987.

[29] M. D. E. De Chavez and M. Capco-Dichoso, "Prevalence of postpartum depression among mothers who delivered in a tertiary hospital," POGS, vol. 3, no. 38, pp. 15-21, 2014.

[30] A. Lanes, J. L. Kuk, and H. Tamim, "Prevalence and characteristics of postpartum depression symptomatology among Canadian women: A cross-sectional study," BMC Public Health, vol. 11, no. 302, pp. 1-9, 2011.

[31] WHO, Gender and women's mental health, 2017. [Online]. Available: http://www. who.int/mental_health/prevention/genderwomen/en/. [Accessed: October 2019].

[32] R. C. Kessler, P. Berglund, O. Demler, R. Jin, K. R. Merikangas, E. E. Walters, "Lifetime prevalence and age-of-onset distributions of DSM-IV disorders in the National Comorbidity Survey Replication," Arch Gen Psychiatry, vol. 62, pp. 593-602, 2005.

[33] M. W. O'Hara and A. M. Swain, "Rates and risk of postpartum depression: A meta-analysis," Int. Rev. Psychiatry, vol. 8, pp. 37-54, 1996. doi: 10.3109/09540269609037816.

[34] D. Kurniasari and Y. A. Astuti, "Hubungan antara karakteristik ibu, kondisi bayi dan dukungan social suami dengan postpartum blues pada ibu dengan persalinan SC di Rumah Sakit Umum Ahmad Yani Metro Tahun 2014," Jurnal Kesehatan Holistik, vol. 9, no. 3, pp. 115-125, 2015.

[35] K. Wijayanti, F. A. Wijayanti, and E. Nuryanti, "Gambaran faktor-faktor risiko postpartum blues di Wilayah Kerja Puskesmas Blora," Jurnal Kebidanan, vol. 2, no. 5, 2013.

[36] B. Major, M. Appelbaum, L. Beckman, M. A. Dutton, N. F. Russo, and C. West, "Abortion and mental health: Evaluating the evidence," American Psychological Association, vol. 64, no. 9, pp. 863-890, 2009. doi: 10.1037/a0017497. [Accessed: October 2019].

[37] A. A. Kadir, M. N. M. Daud, M. J. Yaacob, and N. H. N. Hussain, "Relationship between obstetric risk factors and postnatal depression in Malaysian Women," International Medical Journal, vol. 16, no. 2, pp. 101-106, 2009.

[38] Y. J. Lee, S. W. Yi, D. H. Ju, S. S. Lee, W. S. Sohn, and I. J. Kim, "Correlation between postpartum depression and premenstrual dysphoric disorder: Single center study," Obstet Gynecol Sci, vol. 58, no. 5, pp. 353-358, 2015. doi: 10.5468/ogs.2015.58.5.353.

[39] M. M. Buttner, S. L. Mott, T. Pearlstein, S. Stuart, C. Zlotnick, and M. W. O'Hara, "Examination of premenstrual symptoms as a risk factor for depression in postpartum women," Arch Womens Ment Health, vol. 16, pp. 219-225, 2013. doi: 10.1007/s00737-012-0323-x. [Accessed: October 2019]. 